\title{
SERBIAN AGRICULTURAL COOPERATIVES AND THEIR PATH TOWARDS THE EUROPEAN UNION - LEGAL ASPECT
}

\author{
Gordana Ljubojevićl, Nina Maksimović Sekulić2 \\ *Corresponding author E-mail: nina.maksimovicbg@gmail.com
}

A R T I C L E I N F O
Review Article
Received: 08 December 2020
Accepted: 08 February 2021
doi:10.5937/ekoPolj2101173L
UDC 006.024:349.422.2(497.11)
(4-6EU)

Keywords:

agricultural cooperatives, European integration process, agricultural policy

JEL: Q18, K39

\section{A B S T R A C T}

The association of farmers as a model of sustainable rural development is a significant factor in the rapid development of agriculture and the improvement of the position of agricultural producers. The economic importance of cooperatives in the world and Europe is continuously growing, especially in the conditions of global and regional economic and financial crises, when cooperatives show a high degree of resistance to the shocks of these crises and a high percent of survival on the market. The European Union recognizes the growing role of cooperatives. The European Commission define the cooperative sector as protector and promoter of the European model of social economy, and as an extremely important factor in building and preserving local "social capital" - trust, mutual assistance and horizontal ties between citizens and organizations. New EU members and candidate countries preparing to join the EU, including the Republic of Serbia, should promote cooperatives as a key aspect of economic development and social policy. The aim of this paper is to analyze the current legal position of agricultural cooperatives in Serbia, and to determine the degree of harmonization with EU regulations and comparative analysis of their legal regulation in the EU Member States. Based on the conducted analysis, recommendations will be proposed in order to improve the legislative framework of agricultural cooperatives in Republic of Serbia in order their future successful functioning on the EU market.

(C) 2021 EA. All rights reserved.

1 Gordana Ljubojević Ph..D., Associate Professor, Novi Sad School of Business, Vladimira Perića - Valtera 4, 21000 Novi Sad, Phone:+381 63360 873, E-mail: ljubojevic.vps@gmail.com, ORCID ID (https://orcid.org/0000-0003-0087-3947)

2 Nina Maksimović Sekulić, Ph.D., Assistant Professor, Modern business school Belgrade, st. Terazije 27, 11000 Belgrade, Serbia, Phone: +381 62206 642, E-mail: nina.maksimovicbg@gmail.com, ORCID ID (https://orcid.org/0000-0002-4330-0666) 


\section{Introduction}

The major source of income in rural areas is the agriculture. The dominant support for the development of agricultural producers, marginalized groups (women, youth) is provided by agricultural cooperatives, by creating new jobs and implementing business models. In this way, rural areas become more sustainable and resilient to economic fluctuations. Also, the fresh air is the reason of migratory movement towards rural areas (Bellini et al., 2019; Nicolescu \& Drăgan, 2020). Through cooperation and association, producers have access to new markets, information and technologies, suppliers of raw materials and agricultural machinery, as well as numerous trainings. Furthermore, associating producers facilitates decision-making at all levels."Development and improvement of agricultural cooperatives in Serbia and throughout the developing world is a very important practical task that is based in respect of the principle of agricultural cooperatives and set standards of the European Union and the International Cooperative Alliance - ICA, in which establishment is involved the Association of Serbian agricultural cooperatives together with other national associations.'(Bojić, Vapa Tankosic, 2015).

"Cooperatives are of enormous importance for the agricultural sector in Serbia mainly for the reason of small average surfaces of agricultural holdings of 5.4 ha only, which are divided in more than three plots, on average. (Republic Statistical Office, 2012) In most cases, it is neither possible to organize an efficient and profitable production nor apply modern agronomic practices and new technologies on small holdings. The result of small holdings also reflects on the exportation of agricultural commodities" (Petković, Krasavac, Kovačević, 2016).

Through cooperatives, farmers can achieve numerous benefits: more favorable procurement of wholesale inputs, placement of products without intermediaries, construction of processing plants, purchase of modern machinery, obtaining government incentives and help, hiring experts, etc (Zakić, Nikolić, 2018).

"According to the data of the Cooperative Union of Serbia", since 2017, twice more new agricultural cooperatives have been formed in the central part of the Republic of Serbia in relation to the area of Vojvodina. Evidently, this is the result of the program adopted to improve the work of agricultural cooperatives by "the Government of the Republic of Serbia", where priority was given to the Nisava, Toplica, Jablanica and Pcinja districts (Zakic, Nikolic, 2018).

In EU MS, small, medium and large producers have a need for economic integration into cooperatives. In the most developed EU countries - between $50 \%$ and $98 \%$ of the turnover of all agricultural products is done through cooperatives - this is an indication that large producers are also part of the cooperative system.

\section{Methods of research and sources of data}

Based on the set goals, the analysis of the content of secondary data sources was used as the basic methods of research. Secondary data, information on the EU Agricultural 
cooperatives were taken mostly from the official European Commission documents and relevant literature. The data on the state of the Serbian agrarian sector and cooperatives, as well as the current and potential problems that the RS faces on the basis of the literature on RS agricultural policy, strategic documents, Serbia's Progress Report on the Accession Process.

The paper analyzes the current state of legislation, and the Cooperatives Act, "the Law on companies, the Law on association, the Law on Agriculture and Rural Development" were mostly used in drafting the paper. Data from the Association of Agrarian Economists of Serbia and the study Association of Farmers in the Western Balkan countries, as well as data from the Republic Statistical Office, were used to analyze the position of agricultural cooperatives in Serbia.

\section{Research results}

\section{Legal position of agricultural cooperatives in Serbia}

The main sources of law for this issue are "the Law on Agriculture and Rural Development ("Official Gazette of the RS", No. 41/2009, 10/2013 - other law and 101/2016), the Law on Cooperatives, ("Official Gazette of RS", No. 112/2015), and the Law on Companies of RS (“Official Gazette of RS”, No. 36/2011)".

We consider it necessary to point out certain terms which we will use in our work, for the sake of precision and correct understanding of terms.("Art. 2. The Law on Agriculture and Rural Development") Thus, agriculture is an economic activity that includes those activities that are classified by law as agriculture. "An agricultural holding is a production unit on which a business company, agricultural cooperative, institution or other legal entity, entrepreneur or farmer performs agricultural production. A family agricultural farm is an agricultural farm on which a natural person-farmer together with members of his household performs agricultural production. The holder of a family agricultural holding is a natural person, farmer and entrepreneur who performs agricultural production, and who is registered in the Register of Agricultural Holdings, as the holder of a family agricultural holding. A farmer is a holder or member of an agricultural holding who is exclusively engaged in agricultural production".

"Pursuant Article 3. the Law on Agriculture and Rural Development, Agricultural policy and rural development policy of the Republic of Serbia is implemented through the implementation of the Strategy of Agriculture and Rural Development of the Republic of Serbia, the National Program for Agriculture and the National Program for Rural Development, as well as the IPARD program. The register of agricultural holdings is kept, the contract on the use of incentives is prepared between the Management and the users of incentive funds, as well as decides on the right to incentives. (Art. 8a the Law on Agriculture and Rural Development)" 
There are several types of incentives, (Articles 9-12, "the Law on Agriculture and Rural Development"):

1 / direct incentives, which include:

a / premiums

$\mathrm{b} /$ production incentives

c / regression

d / support to non-commercial agricultural holdings

2 / market incentives, such as:

a / export incentives

b / storage costs

c / credit support,

3 / structural incentives, where we mention:

a / rural development measures

b / improving the protection and quality of agricultural land

c / institutional support measures

In the following text, we will deal with agricultural cooperatives as a form of performing agricultural activities on agricultural farms. Agricultural cooperatives, as well as companies, and other legal entities, such as institutions, schools, monasteries, churches and other organizations, entrepreneurs and farmers engaged in agricultural production are entered in the Register of Agricultural Holdings, as users of agricultural land on the basis of:

- property rights,

- decisions on consolidation,

-leasing agreement

- transfer of agricultural land for use ("Art. 21. the Law on Agriculture and Rural Development").

With the day of registration, the cooperative acquires the status of a legal entity, unlike the branch, as a separate organizational part through which the cooperative can perform activities, and which cannot have that status. It may not be organized as a company, nor may it be merged or merged with another company or legal entity that is not a cooperative, nor may it change its form into a company or other legal entity. On the other hand, it can be the founder, ie a member of another legal entity, and in accordance with the law and cooperative rules. The cooperative has its own business name, headquarters (as the place from which the business of the cooperative is managed), as well as the 
activity, which are all elements of its individualization. The predominant activity of the cooperative determines the type of cooperative. Agricultural or agricultural cooperatives can be established as general and specialized (when they deal with the organization of production of certain products, their processing and marketing). Otherwise, they take over and buy, process and sell agricultural, food and other products of cooperatives and cooperatives, supply cooperatives with reproductive material, energy, means of production, parts for agricultural machinery and other goods, trade goods and services of cooperatives, cooperatives, and for cooperatives and provide services to farmers' households in organizing and developing rural tourism and perform all other tasks of interest to the cooperative's business (Art. 11. Item. 1 and 2. Law on cooperatives).

Foundation of a cooperative (Articles 14-22, Law on cooperatives) implies:

\section{1 / Convening of the founding assembly}

The cooperative can be founded by at least five able-bodied domestic or foreign natural persons, deposits or membership fees, in accordance with the founding agreement and cooperative rules, by convening the founding assembly by the representatives of the founders. The contributions of the co-operative members form the basic capital of the co-operative, and can be monetary or non-monetary (when they are expressed in monetary equivalent). The minimum share capital of the cooperative is 100 dinars, and the rules of the cooperative determine the minimum individual contribution. A co-operative member may have only one stake in the co-operative, and the stakes need not be equal. Deposits cannot be transferred by legal transaction. When a cooperative is established by the membership fee of the cooperative member, the amount of the membership fee is determined by the cooperative rules in the same amount for all founders, as well as cooperative members who later join the cooperative, and after the establishment.The founding assembly implies a quorum of at least five founders, and decisions are made by a majority vote of those present, provided that a minimum of five votes of the founders is required for valid decision-making. The founders are obliged to pay the contributions, ie membership fees, within 30 days from the day of the founding assembly.

2 / Concluding a memorandum of association, implies that it be made in writing, where the signatures of the founders must be certified (ie, a special written legal form). The memorandum of association contains provisions on the business name, registered office, predominant activity of the cooperative, designation of the cooperative member, and designation of the first director, ie the person who will represent the cooperative as acting director, information on whether the cooperative operates membership fees or contributions. payment of the monetary contribution of each founder, description of the type, value, manner and time of entering the non-monetary contribution of each founder, amount, time and manner of payment of membership fees for founders of cooperatives established and operating without deposits, manner of providing funds to cover importance for the establishment of a cooperative. 
3 / Adoption of cooperative rules, which are a general act of the cooperative which, above all, regulates the management and operations of the cooperative, the internal organization of the cooperative, as well as other issues in accordance with the law (thus, the rights and obligations of cooperatives capital, manner and conditions of increase or decrease of the share capital of the cooperative, formation of the management and supervisory board, distribution of profits and loss coverage, status changes and termination of the cooperative, manner of determining and paying contributions to cooperative members in case of termination of cooperative status

4 / Selection of bodies. The cooperative is managed by the cooperative members, and they have the same right to vote, according to the principle of "one cooperative member, one vote" in the assembly of the cooperative. The bodies of the cooperative are: the assembly, the board of directors, the supervisory board and the director. The provisions of the law governing the position of companies shall apply accordingly to the responsibility of the members of the cooperative's bodies, in the part which regulates special duties towards the company, unless otherwise provided by law. The specificity is that the president of the assembly, president and members of the board of directors, supervisory board and director are elected for a period determined by the cooperative rules, which cannot be longer than five years, with the possibility of re-election. If the cooperative has less than twenty members, it can be envisaged that the assembly of the cooperative performs the function of the management and supervisory board of the cooperative. (Art. 34 Law on Cooperatives). The quorum for the Assembly, Management and Supervisory Board is more than half of the total number of members, and decisions are made by a majority vote of the total number of members present, except in cases referred to in Article 36. Law on cooperatives, which stipulates that the competent body of the cooperative decides on status changes, sale of immovable property, adoption of amendments to the founding act and cooperative rules by a majority vote of the total number of cooperative members, while a two-thirds majority of the total number of cooperative members decides on initiating liquidation proceedings.

\section{Jurisdiction of Assembly, Board of directors and Supervisory Board}

The assembly of the cooperative has competencies (art. 31.Law on cooperatives) which we could classify in:

a) Status-legal and election, which includes the adoption and amendment of the founding act, cooperative rules, as well as the rules of procedure, deciding on changes in the elements of individualization, as well as the type of cooperative or branch closure, status changes and termination of the cooperative company and other legal entity, election and removal of the president and members of the board of directors, and the president and members of the supervisory board, election and dismissal of the director of the cooperative, appointment and dismissal of the liquidator

b) Mostly business, where we can classify the establishment of business policy of the cooperative, the adoption of development programs, financial plan and work plans, adoption of business reports, investment decisions and decisions on the disposal of assets 
c) Mostly financial, in terms of decisions to increase and decrease the share capital of the cooperative, education or closing of funds for various purposes, adoption of annual accounts and business reports and financial statements, deciding on profit distribution and loss coverage, investment decisions, decides on cooperative audits and the selection of the audit association, as well as considers their final report and the actions taken to eliminate any irregularities

Assembly sessions can be regular (held once a year, before the deadline for submission of regular annual financial reports) and extraordinary (held as needed or when determined by cooperative rules) (Article 38 of the Law). If the cooperative has more than 100 cooperative members, the cooperative rules may determine the manner of their representation in the assembly, provided that the representatives cannot decide on the status changes of the cooperative, termination of the cooperative and disposal of its property (Article 39 of the Law).

The Board of Directors consists of at least three members who are elected from among the members of the cooperative, at the assembly of the cooperative (Article 40 of the Law on cooperatives). The competencies of the board of directors (Article 37 of the Law on cooperatives) have the character of:

a) competencies of the executive body (proposes and implements the business policy of the cooperative, work plan, financial plan and development program, considers and proposes business reports, as well as adoption of financial reports, prepares draft decisions for the cooperative assembly and executes its decisions, proposing profit distribution and way of covering losses, proposes to the assembly the election and dismissal of the director, proposes the adoption of investment decisions, as well as decisions on the disposal of assets

b) Decision-making bodies (adoption of rules of procedure and performance of other tasks determined by law, the founding agreement and cooperative rules.

The members of the board of directors are required to perform their functions conscientiously, honestly and responsibly towards the cooperative with the attention of a good businessman and in accordance with the interests of the cooperative and the cooperative members. If cooperatives cause damage, they are responsible for it. (Art. 42 the law on cooperatives) The Supervisory Board consists of at least three members, who are elected from among the members of the cooperative. Its competence includes:

a) Supervision over the work of the Board of Directors and the Director

b) Review of financial and other reports, as well as business reports, and inform the Assembly about it

c) Controls the compliance of the cooperative's operations with the law and the cooperative rules

d) adopts the rules of procedure for its work, 
e) Performs other tasks, in accordance with the law and cooperative rules. (Art. 44 the law on cooperatives)

The director of the cooperative organizes and manages the business of the cooperative, represents the cooperative, takes care of the legality and is responsible for the legality of the work of the cooperative, prepares the work plan, development program of the cooperative, as well as the business report, financial reports. Other activities determined by law, founding act and cooperative rules. (Art. 48 the Law on Cooperatives)

The current situation in the cooperative is not such that we can be proud of it. While in many European countries cooperatives supply the market with their products in more than dominant percent, in Serbia the situation is almost the opposite, and cooperatives in Serbia contribute with only $1.5 \%$ of gross value added of agricultural production. The state's lack of interest in this area is clearly reflected in the lack of precise statistical data on the shares of cooperatives in certain areas of agricultural production. Also, other forms in which association can be implemented have not been sufficiently used. There are numerous obstacles to this, some of which relate to the poor legal framework and others to the lack of information of farmers, and the lack of ambition to find alternatives to traditional forms of association when they fail.

\section{Legal status of agricultural cooperatives in the $\mathrm{EU}$}

"The EU is guided by its Common Agricultural Policy (CAP) and its guidance on producer organizations, the CAP gives each of the 27 member states of the EU a level of autonomy in how they individually define and support APCs and whether they incentivize or discourage cooperative participation. In the he EU, there is a huge variety of national laws on cooperatives, which correspond to at least six formally different models of legislation: - no cooperative law (e.g. Ireland); - cooperative regulation in a formally independent act (e.g. Austria, Germany); - cooperative regulation in the commercial code (e.g. Czech Republic, Slovakia); - cooperative regulation in the company law (e.g. Luxembourg) or in the companies code (e.g. Belgium); - cooperative regulation in the civil code (e.g. Italy, the Netherlands); - cooperative regulation in the code of cooperatives (e.g. Portugal). A few countries, such as Japan, even have separate cooperative laws for each sector. The United States, on the other hand, do not have a specific federal law on the establishment of cooperatives, but federal law does apply to cooperatives' tax exemptions. With each of the 50 states having its own statutes on cooperatives, these add up to approximately 85 in total. In many countries, cooperatives can have a legal status either as a cooperative society with limited or unlimited liability, as an economic interest grouping or as a joint-stock company. There are also diverging national requirements regarding members and capital stock. A minimum number of members are not always required by law. Some countries have no mandatory provisions in this regard (e.g. Bulgaria, Denmark, Luxembourg), while others require the presence of at least three members (e.g. Germany, Sweden, USA), and yet others require even more. For instance, Poland requires 10 natural persons or three legal entities to set up and run an agricultural cooperative, while Japan requires a minimum of 15 members (European Parliamentary Research Service, 2019)". 
In each of the EU member states, agricultural cooperatives have a different form and type, while their basic principles of organization and functioning are regulated by a directive of the European Council. There are three different levels of organization of agricultural cooperatives in the Union. The first level is first-class cooperatives as a simple form of association. The second levels are second-class cooperatives that collect or process agricultural products. The tertiary level consists of national and regional cooperatives and represents strong financial, commercial and industrial groups (basic focus - product processing and marketing).

At the level of the European Union, the countries with the largest network of cooperatives are: Italy, Greece, Germany, Spain, and France. But the greatest economic power lies in agricultural cooperatives in the following countries: France, Germany, Denmark, and the Netherlands. In Greece, Spain, Italy, the number of cooperatives is large, but despite this, their power is smaller.

It is also necessary to emphasize the horizontal and vertical organization of cooperatives and cooperative associations in the form of cooperative agricultural and food chains. Economic agents from each branch of the chain from the primary to the tertiary level perform horizontal cooperation. Individual farmers and associations create vertical cooperation.

In the EU market, agricultural cooperatives account for a large share, with differences from country to country and from product to product. (Borst, 2017).

\section{European Cooperative}

The basic principles of cooperatives in the countries of the European Union are (Jurić, 2006):

- voluntary and open membership,

- democratic governance of members,

- members are owners - they control the cooperative and its assets,

- autonomous and independent organization

- $\quad$ providing education and training for members,

- cooperatives cooperate with each other,

- cooperatives care about their community.

"According to Council Regulation (EC) no. 1435/2003 of 22 July 2003 on the Statute for a European Cooperative Society, a cooperative is an independent association of persons who unite on a voluntary basis to meet their common economic, social and cultural needs through joint ownership and democratic control of the enterprise". Cooperatives differ in many elements from profit-oriented companies. It differs in the way decisions are made because the principle of "one member vote" is applied or the number of votes of an individual member is limited, the shares of individual members in the share capital are equal, the return on profit is limited and proportional to which 
gives the advantage of the cooperative as a flexible legal form for performing economic activity on the market (Jurić, 2006).

A member of a European cooperative is liable for the obligations of the cooperative up to the amount of the paid business share, unless otherwise provided by the statute. The basic precondition for the establishment of a European cooperative is that the founders have their permanent residence, i.e. that they have nationality in at least two different EU member states. In the case of a legal person, it is established under the law of a Member State and has its registered office and central administration located in the EU. The rules on the European Cooperative Society have been in force since the summer of 2006. The aim of these regulations is to establish a single legal position for cooperatives in the EU internal market for economic activities where the emphasis is not on profit but on promoting the common interest of cooperative members and the community. Therefore, cooperatives are particularly suitable for small and medium enterprises. Cooperatives are defined as open voluntary associations of persons united to meet common economic, social and cultural goals. They achieve their goals through joint ownership and a democratically controlled enterprise. Cooperatives are companies that serve the needs of their members who contribute to their capital. Every country in Europe has its own strategy for economic growth and development through cooperative policy.

A European cooperative is registered within the European Union in the same Member State as its management headquarters. The basic goal is to meet the needs of its members and / or the development of their economic and social activities by concluding an agreement on the supply of goods and services or the execution of works performed or commissioned by the European Cooperative Society. A European cooperative may be set up by: "five or more natural persons residing in at least two Member States; five or more natural and legal persons residing or having their registered office in at least two Member States; legal persons established in at least two Member States". A European cooperative may also be established by merging cooperatives from at least two Member States; by transforming the cooperative if it has had a subsidiary or branch in another Member State for at least two years. The share capital divided into shares of members is at least $€ 30,000$ denominated in local currency. It is variable and its change does not require a change in the statute.

Beside the Assembly, the bodies of the European Cooperative Society are the Supervisory Board and the Management Board or only the Supervisory Board. The founders of the European Cooperative Society adopt the statute. The statute shall at least include: the name before or after which the abbreviation "European Cooperative" must appear; goal and activity of the cooperative; name of natural persons and name of legal entities of the founder of the cooperative; cooperative headquarters; conditions and procedure for admission to membership; rights and obligations of members; nominal value of shares, amount of subscribed capital; special provisions.

It can be concluded that cooperatives are defined as open voluntary associations of persons united to meet common economic, social and cultural goals. They achieve their 
goals through joint ownership and a democratically controlled enterprise. Cooperatives are companies that serve the needs of their members who contribute to their capital. Cooperatives have a great influence on the contribution to the development of the European economy. Every country in Europe has its own strategy for economic growth and development through cooperative policy (Jurić, 2006).

Cooperatives have proved particularly effective in times of crisis, especially with their contribution to economic and financial stability and job retention and job creation. Cooperatives contribute to improving the European transport and energy system and in particular to improving communication infrastructure and services in isolated areas. There is an increase in small and medium-sized cooperatives in all service and manufacturing sectors. They are a local alternative to global trade. Many cooperatives have provided women with the opportunity to become entrepreneurs and have access to decent work: they have improved access to credit, products and market information, technology, and training in the areas of cooperative management and development. Cooperatives direct a significant part of their resources to the education and training of their employees. Cooperatives provide sustainable jobs to disadvantaged workers, such as people with disabilities, the long-term unemployed and the socially marginalized. Cooperatives participate in Erasmus for Young Entrepreneurs (international exchange). There are cooperative universities that have the support of cooperatives, but globally - the education system ignores cooperatives. It can be concluded that cooperatives contribute to the EU 2020 strategy through various business activities. The goals, knowledge and experience of cooperatives and cooperative members should perfectly overlap with many EU 2020 goals.

\section{COPA - COGECA}

COPA- Committee of Professional Agricultural Organizations consists of over 60 organizations, of which 27 organizations are from EU member states, and 36 partner organizations are from other European countries such as Iceland, Norway, Switzerland and Turkey. The basic competencies are:

- consideration of all issues related to the development of the Common Agricultural Policy;

- representing the interests of the agricultural sector as a whole;

- seeking solutions that are of common interest;

- Maintaining and developing relations with EU bodies and any other representative organizations or social partners established at European and world level.

The activities are organized in 50 working groups, which deal with specific issues related to agricultural production (cereals, beef) or general issues (environment, rural development). Most of these working groups are made up of members from both organizations, but COPA and COGECA also have independent working branches. The working structures of COPA-COGECA determine three basic ideas: 
- enabling representatives of the European Union from different agricultural production sectors and areas to discuss issues related to a particular sector or area;

- coordination of work in the overall context of agriculture, agricultural policy and policy in general;

- Joint representation of all sectors and areas.

COGECA, a member of the International Alliance of Cooperatives, has 35 full members from EU member states, four associate members and 36 partner organizations, which include representatives of countries such as Switzerland, Norway, Iceland and Turkey. COGECA is also a member of the Cooperative of Europe, ie the International Alliance of Cooperatives (ICA), and the current president of this COGECA is the Swede Thomas Magnusson. The most important COGECA goals:

- Representing and defending the general and specific interests of European agricultural, forestry and fisheries cooperatives and contributing to the development of cooperatives in general;

- Influencing decisions related to the activities of agricultural cooperatives by lobbying EU public institutions and other organizations at EU and international level;

- promotion of the role of agricultural, forestry, fishing and agricultural cooperatives;

- providing a platform for EU member organizations and cooperatives to hold policy discussions and exchanges on policy issues and add value to agricultural products and businesses;

- seeking and promoting solutions to important issues of general interest;

- Facilitating and coordinating links between its members and its members' offices in Brussels, as well as providing cooperative networking services;

- Promoting discussion and exchange of views with COPA and other representatives of organizations at the level of the European Union and at the international level;

- Conducting legal, economic, financial, social and other analyzes and studies of interest to agriculture, forestry, fisheries and agri-food cooperatives.

Due to all the above, it is clear that COPA and COGECA are very important organizations of farmers, who are fighting for the realization of their interests in the European Union and abroad. To this end, the two organizations work closely with the European Commissariat for Agriculture and Rural Development and discuss all key issues related to the Common Agricultural Policy (CAP), food production, agricultural market, rural development and environmental protection. 


\section{Recommendations for improving the position of agricultural organizations in the $\mathbf{E U}$ accession process}

"The Serbian agriculture sector in the past decades, after all the negative challenges that it faced in the past, experienced a serious economic downturn and economic crisis. Recovery of Serbian agriculture and rural development, economic growth and competitiveness of agricultural products, improvement of standards and preservation of the environment, are possible only with the integration and implementation of CPU regulations. In recent years, Serbia has embarked on systemic and structural reforms of the agrarian sector “(Maksimovic Sekulic, Živadinović, Dimitrijevic, 2018).

Cooperatives are the second largest form of association of farmers. They are established to represent the interests of their founders, to provide advisory services (taxes, legal issues), cooperation with donors, other associations and institutions. According to the Association of Farmers data in the Western Balkan countries, there are 724 farmers' associations in Serbia, of which, however, as many as 409 are inactive. More than $80 \%$ of these associations were formed in the period from 2000, so some of them can be seen as an escape of farmers from the legal uncertainty that exists in the cooperative sector. Associations, unlike cooperatives, are usually specialized, and beekeepers' associations are the most organized.

In large part, agricultural producers in the Republic of Serbia, uncompetitive to agricultural producers in the EU, and that agricultural holdings are largely fragmented and not strong enough to withstand competition in the market, it is necessary to focus the current unorganized agricultural production on association and joint planning in ordet to increase the volume and quality of yield that would be easier to place on the market through organized associations, cooperatives. Accordingly, it is necessary to inform about the possibilities of cooperative organization, to raise awareness about the need and importance of association, to encourage personal initiatives among producers.

In the EU accession process, it is necessary to harmonize domestic regulations, but also to constantly monitor and listen to the needs of agricultural producers in order to improve them, which can be improved by joining and the need to separate a certain percentage of profits, to finance joint activities, which have been transferred to the cooperative, as their service for easier market access and production improvement. It is also necessary to provide measures to raise awareness of the need to cooperate with the scientific community in order to improve production and increase innovation and thus product value, which is more easily achieved through the cooperative, so that the needs are properly transferred and included in the development of strategic documents related to agricultural production and development, as well as protected from the shocks that market liberalization may cause. This protection is achieved by harmonizing monitoring and planning and thus by timely anticipating the challenges that may arise.

State incentives for development projects are crucial in improving competitiveness. (Employment incentives, tax breaks; improving the knowledge of cooperatives and http://ea.bg.ac.rs 
management in cooperatives...etc). In that way, the state would have an active role in solving the huge problems in which the agriculture of Serbia finds itself, which is also the economic branch with the largest net exports. If all or at least part of the potential that Serbian agriculture has was realized, this export balance could be further improved in a short time. This could have an even greater impact on strengthening the food industry, as well as attracting investors in this area, and the state must and should take all necessary steps in this direction.

After the accession of the Republic of Serbia to the European Union, as well as other EU MS, there will be two models of cooperatives, according to "the law of the Republic of Serbia and at the level of the European Economic Area cooperatives established under the Regulation". Over time, the content differences between these two forms will gradually diminish. However, it is right to expect that cooperatives will preserve their identity as independent organizational forms and those they will contribute to the affirmation of cooperative law. The European Cooperative Society is also in a special property law system.

\section{Conclusions}

The large part of agricultural producers in the Republic of Serbia are uncompetitive to agricultural producers in the EU, and agricultural holdings are largely fragmented and not strong enough to withstand competition in the market, it is necessary the current unorganized agricultural production direct on association and joint planning in order to obtain the volume and quality of yield that would be easier to place on the market through organized associations-cooperatives. In order to achieve this, more active participation of state institutions and the non-governmental sector is needed in the coming period in order to support any serious initiative of associated agricultural producers. Association in cooperatives brings additional benefits for the population in rural areas because it does not require clear differentiation, ie conditionality that all members are engaged in the production of the same agricultural products or engaging in similar activities. The cooperative also enables the connection of production and supply chains, which are best reflected in the development of rural tourism, as a secondary activity in relation to primary agricultural production. The members of the cooperative can provide tourist services in the field of rural tourism, and they give additional value to these services by serving domestic agricultural products from the same environment, as well as products of domestic handicrafts. In the process of negotiations on EU membership, it is necessary to harmonize domestic regulations, but also to constantly monitor and listen to the needs of agricultural producers in order to improve them, which can be improved by joining and the need to set aside a certain percentage of profits to finance joint activities that were transferred to the cooperative, as their service for easier access to the market and improvement of production. It is also necessary to envisage measures to raise awareness of the need for cooperation with the scientific community in order to improve production and increase innovation, and thus the value of products, which is more easily achieved through the cooperative. 
needs were appropriately communicated and included in the development of strategic documents related to agricultural production and development, as well as protected from the shocks that market liberalization may cause. This protection is achieved by harmonizing monitoring and planning and thus by timely anticipation of challenges that may arise.

In order to financially support the development of associations of agricultural producers, it is necessary for the Government and line ministries of agriculture, economy and finance to develop incentive financial mechanisms for association of agricultural producers (subsidies, soft loans, incentive tax policy, etc.), and in particular to provide individual agricultural producers with access to the funds of the Development Fund; · It is necessary to improve the work of advisory services of the Ministry of Agriculture and Environmental Protection on the issue of providing assistance to agricultural producers during the establishment and the first years of operation of cooperatives. The assistance of advisors should be reflected in providing information on the importance and possibilities of association of agricultural producers, regulations, sources of funding, as well as information on the work of state and local institutions relevant to the functioning of cooperatives.

In this way, the state would have an active role in solving the huge problems of Serbian agriculture, which is also the industry with the largest net exports. If all or at least part of the potential that Serbian agriculture has was realized, this export balance could be further improved in a short time. This could have an even greater impact on strengthening the food industry, as well as attracting investors in this area, and the state must and should take all necessary steps in this direction. Activities of state bodies in the process of rehabilitation of cooperatives in Serbia should be aimed at building a modernly organized cooperative, integral in business terms, autonomous and stimulating for the owners of agricultural farms who through cooperatives can realize their production, business and other interest. The activities of state bodies in this area should primarily relate to the regulation of the legislative framework, tax treatment and the availability of sources of funding for cooperatives in Serbia.

The acceptance of this Statute for a European Cooperative commits the member states to adopt measures to implement and incorporate into their national regulations some provisions of the Directive to the workers involved in the decision making process of SCE. The European Commission considers "that this is a good benefit for the national governments and investors to pile on initiatives to improve cooperative legislation and create a more favorable environment for their development. Republic of Serbia on its path towards the European Union is bound to meet these tasks if it wants to become part of unique agricultural markets and to improve its agricultural cooperatives and the approaches to the legal and organizational standards of the European Union, which is certainly an imperative".

Starting from the experiences of EU countries, the supporting measures for cooperatives development could include certain tax breaks and subsidies for cooperatives. From 
the of particular importance is the amendment of legislation that would allow again establishment of savings and loan cooperatives, which are key factor in cooperative sector of EU countries. Finally, all measures to support the development of cooperatives in Serbia, both current and future, they must be accompanied by an appropriate cooperative control system, in order to avoid abuse of business in this legal form of enterprise.

\section{Conflict of interests}

The authors declare no conflict of interest.

\section{References}

1. Bellini, F., Dulskaia, I., Savastano, M., \& D’Ascenzo, F. (2019). Business models innovation for sustainable urban mobility in small and medium-sized European cities. Management \& Marketing. Challenges for the Knowledge Society, 14(3), 266-277. https://doi:10.2478/mmcks-2019-0019

2. Birchall, J. \& Ketilson Lou, H. (2009). Resilience of the Cooperative Business Model in Times of Crisis. International Labour Organization

3. Borst, A. (2017). Agricultural production cooperatives in the e.u.: explaining variation in cooperative development, Sally McDonnell Barksdale Honors College The University of Mississippi.

4. Census of Agriculture 2012 (2012). Republic of Serbia: Republic Statistical Office, Retrieved from http://popispoljoprivrede.stat.rs/ (November 1, 2020).

5. Cogeca (2015). Development of Agricultural Cooperatives in the EU 2014, 5 February 2015, Brussels.

6. Cooperatives Europe (2016). The power of cooperation-Cooperatives Europe key figures 201. Brussels.

7. Council Regulation (EC) no. 1435/2003 of 22 July 2003 on the Statute for a European Cooperative Society.

8. Czachorska-Jones, B., Finkelstein, J.G., \& Samsami, B. (2013). 'United States', in Fici et al. (eds.): International Handbook of Cooperative Law, 759-778.

9. Fici, A. (2012). Cooperative identity and the law, EURICSE Working Paper, No. 023.

10. Fici, A. (2017). A European Statute for Social and Solidarity-Based Enterprise, Policy Department for Citizens' Rights and Constitutional Affairs, European Parliament.

11. Fici, A., Cracogna, D., \& Henrÿ, H. (2013). International Handbook of Cooperative Law, Berlin/Heidelberg, Springer.

12. Guide through Farmers' Cooperatives, (2012), Belgrade.

13. Henrÿ, H. (2012). Guidelines for Cooperative Legislation, third revised edition, ILO, Geneva. 
14. ICA(International Cooperative Alliance) and EURICSE (2018). World Cooperative Monitor, Exploring the Cooperative Economy, Report.

15. Jakob, D., Huber, R., \& Rauber, K. (2009). Nonprofit Law in Switzerland, The Johns Hopkins Comparative Nonprofit Sector Project, Working Paper No 47.

16. Jurić, D. (2006). European cooperative society (SCE), Law and taxes, 6.

17. Kurimoto, A. (2013) in: Fici et al. (eds.): International Handbook of Cooperative Law, 503-523.

18. Law on Agriculture and Rural Development ("Official Gazette of the RS", No. 41/2009, 10/2013 - other law and 101/2016).

19. Law on Cooperatives, (“Official Gazette of RS”, No. 112/2015).

20. Law on Companies of RS (“Official Gazette of RS”, No. 36/2011).

21. Liger, Q., Stefan, M., \& Britton, J. (2016). Social Economy, Policy Department for Economic and Scientific Policies, European Parliament.

22. MacDonald, T., Wallace, G., \& MacPherson, I. (2013). Co-operative Enterprise Building a Better World. Sarasota: Global Co-operative Development Group, Inc.

23. MacPherson, I. (1996). Co-operative Principles. International Co-operative Information Centre, ICA/UWCC.

24. Maksimović Sekulić, N., Živadinović, J., \& Dimitrijević, Lj. (2018). Concerns about hamonization process of Serbian agricultural policy with EU standards. Economics of Agriculture, 65(4), 1627-1639. https://doi.org/10.5937/ekoPolj1902617D

25. Mazzarol, T. Simmons, R., \& Limnios, M. (2011). A conceptual framework for research into co-operative enterprise, Centre for Entrepreneurial Management and Innovation (CEMI), Discussion Paper 1102.

26. Measuring the Size and Scope of the Cooperative Economy: Results of the2014, Global Census on Co-operatives. (2014). United Nation's Secretariat, Department of Economic and Social Affairs, Division for Social Policy and Development. Retrieved from http://www.un.org/esa/socdev/documents/2014/coopsegm/grace. pdf (November 15, 2020)

27. Nikolić, M. (2009). Evolution of cooperative legislation in Serbia, Society of Agricultural Economists of Serbia, Belgrade.

28. Nikolić, M. (2014). Implementation of cooperative values and principles and their influence on business of agricultural cooperatives in Serbia, University of Belgrade, Faculty of Agriculture.

29. Nicolescu, A. F., \& Drăgan, G. (2020). Integrating the non-EU immigrants into the EU labour market. An econometric analysis of some of the specific factors. Management \& Marketing. Challenges for the Knowledge Society, 15(3), 364-380. https:// doi: 10.2478/mmcks-2020-0021. 
30. Petković, G., Chroneos-Krasavac, B., \& Kovačević, V. (2016). A critical review of legal framework as a factor of coops development: Case of Serbia. Economic of agriculture, 63(1), 261-278. https://doi.org/10.5937/ekoPolj1601261P

31. Program of support for the implementation of measures for balanced regional development of the Republic of Serbia through the participation of the state in economic and financial incentives for cooperatives in 2018. Government of the Republic of Serbia.

32. Rulebook on cooperative audit of cooperative union. Ministry of Economy of the Republic of Serbia, Retrieved from http://www.privreda.gov.rs/test-2 (November 2, 2020).

33. Rixon, D. (2013). Are co-operative principles reflected in performance reporting? a case study of insurance co-operatives. International journal of co-operative management, 6(2), 76-90.

34. Study on the implementation of the Regulation 1435/2003 on the Statute for European Cooperative Society (SCE), (2010) EURICSE (European Research Institute on Cooperative and Social Enterprises).

35. Thirion, E. (2017). Statute for social and solidarity-based enterprises, EPRS, European Parliament.

36. Widuto, A. (2017). EU support for social entrepreneurs, EPRS, European Parliament.

37. Zakić, V., \& Nikolić, M. (2018). State financial support to cooperatives in Serbia. School of business, $158-174$.

38. Zakić, V., Nikolić, M., \& Tasić, V. (2018). The possibilities of improving the regulative and methodology of the cooperative audit in Serbia, Reviser, 82/2018, 57-68. 